\title{
KEPEMIMPINAN KEPALA SEKOLAH DALAMMENINGKATKAN MUTU PENDIDIKAN
}

\author{
Abdul Kholid Achmad \\ e-mail : abdkholidachmad@gmail.com \\ Praktisi Pendidikan di Kota Malang
}

\section{Abstract}

As an educational leadership, principals have a duty and responsibility which is quite heavy. Principals through their role and responsibilities to delegate it to aides and other parts. principal leadership in improving the quality of education include: instructive leadership style, leadership style consultative, participative leadership style, delegative leadership style and the quality of education through the process of determining the in-put and out-put processes (graduate).

Efforts to improve the quality of school education is needed coaching to teachers and employees by the principal through (1) leadership style instructive addressed to teachers and employees who lacked the academic ability and spirit of performance is less, (2) a consultative leadership style in fostering the ability of teachers and employees of academic less and and the spirit of good works, (3) participative leadership style in fostering teachers and employees who have good academic ability and less fervor employees who have good academic ability, and excellent in performance.

Keywords: Principal, The Quality of Education

\section{Abstrak}

Kepemimpinan sekolah memiliki tugas dan tanggung jawab yang cukup berat. Kepala sekolah melalui peran dan tanggung jawabnya untuk mendelegasikan kepada para wakil dan bidang terkait. kepemimpinan kepala sekolah dalam meningkatkan mutu pendidikan meliputi: gaya kepemimpinan instruktif, gaya kepemimpinan konsultatif, gaya kepemimpinan partisipatif, gaya kepemimpinan delegatif dan kualitas pendidikan melalui proses penentuan in-put dan out-put.

Untuk meningkatkan kualitas pendidikan sekolah diperlukan pembinaan untuk guru dan karyawan oleh kepala sekolah melalui (1) gaya kepemimpinan instruktif ditujukan kepada guru dan karyawan yang tidak memiliki kemampuan akademik dan semangat kinerja kurang, (2) gaya kepemimpinan konsultatif membina kemampuan guru dan karyawan akademik kurang dan dan semangat kerja yang baik, (3) gaya kepemimpinan partisipatif dalam membina guru dan karyawan yang memiliki kemampuan yang baik akademik dan karyawan semangat kurang yang memiliki kemampuan akademik yang baik, dan sangat baik dalam kinerja.

Kata kunci: Kepala Sekolah, Kualitas Pendidikan

\section{Pendahuluan}

Kepemimpin pendidikan di sekolah atau yang sebut kepala sekolah, melalui perannya untuk mengorganisasikan sekolah dan personilnya yang bekerja secara efisien, demokratis dan kerja sama institusional yang tergantung keahlian para pekerja. Dibawah kepemimpinannya program pendidikan untuk siswa harus direncanakan, diorganisasikan dan didata. Dalam pelaksanaan program, kepala sekolah yang baik harus dapat memimpin secara profesional kepada para staf pengajar, bekerja secara ilmiah, penuh perhatian, dan demokratis, dengan menekankan pada perbaikan pendidikan. Dengan demikian bahwa kepala sekolah secara teoritik bertanggung jawab atas 
penyelenggaraan seluruh program pendidikan di sekolah.

Kaitannya kepemimpinan kepala sekolah dan pembinaan pendidikan, bahwa pendidikan nasional telah tertuang dalam UU No. 20 Tahun 2003, pasal 14 (2003) disebutkan bahwa jenjang pendidikan formal terdiri dari pendidikan dasar, pendidikan menengah, dan pendidikan tinggi.

Setiap memasuki awal tahun ajaran baru, orang tua yang ingin menyekolahkan anak-anaknya ke SD, SLTP, SMU atau perguruan tinggi dengan harapan memperoleh sekolah yang dipandang baik. Kriteria baik, sebenarnya bersifat kompleks, sebab menyangkut banyak variabel yang terkait satu sama lain, akan tetapi secara umum masyarakat atau orang tua cenderung menunjuk pada faktor umum bahwa sekolah yang baik memiliki kualitas akademik yang baik (Kurniawan, 1996 : 2). Menurut Davis dan Thomas (1996) terdapat lima faktor yang memberikan kontribusi terhadap suksesnya suatu sekolah dalam menjalankan programnya, antara lain : (1) kepemimpinan (administrasi dan pengajaran) yang kuat; (2) ekspektasi (harapan yang tinggi dari guru-guru, disertai perilaku yang sesuai harapan tersebut; (3) iklim akademik; (4) pengajaran yang ditekankan pada ketrampilan dasar; (5) peitilaian kemajuan siswa secara kontinue.

Namun demikian keberhasilan suatu sekolah sangat ditentukan oleh proses belajar mengajar (PBM) yang tertib, efektif dan efisien. Proses belajar mengajar (PBM) dapat berjalan dengan tertib, efektif dan efisien apabila seluruh komponen yang berpengaruh dalam PBM saling mendukung dalam rangka mencapai tujuan komponen-komponen yang berpengaruh tersebut antara lain meliputi; siswa, kurikulum, guru, metode, sarana dan prasarana, dan lingkungan. Namun, beberapa komponen tersebut yang paling menentukan adalah guru. Potensi guru ini dapat berperan secara optimal, jika kepala sekolah selaku pimpinan pendidikan mempunyai peranandalam proses pelaksanaan pendidikan di sekolah hal tersebut dikarenakan kepala sekolah sebagai pimpinan memiliki tugas dan tanggung jawab yang komprehensip.

Penelitian sekolah yang efektif dikaitkan dengan keberhasilan kepemimpinan kepala sekolah seperti yang dilakukan Sergiovani (1987) yang menemukan fakta bahwa sekolah yangprestasi muridnya tinggi, memiliki kepala sekolah yangterlibat secara langsung. Dari hasil penelitian yang dilakukan oleh para ahli manajemen pendidikan tersebut di atas dapat diketahui salah satu faktor pendukung dan kunci keberhasilan bagi sekolah sukses atau sekolah berprestasi adalah faktor kepemimpinan kepala sekolah.

\section{Kepemimpinan Kepala Sekolah \\ 1. Pengertian Kepemimpinan}

Robin dalam H.A Tilaar (1992) mendifinisikan kepemimpinan adalah, kemampuan untuk mempengaruhi suatu kelompok kearah pencapaian tujuan. Pendapat senada dipaparkan bahwa kepemimpinan adalah proses mempengaruhi aktivitas-aktivitas kelompok yang terorganisasi terhadap perumusan tujuan dan pencapaian sebagaimana pendapat Stogdill (Purwantoro:1997). Sementara Hemphill dan Coons dalam Yulk, mengatakan bahwa kepemimpinan adalah perilaku individual saat ini menggerakkan aktivitas kelompok untuk mencapai tujuan (Purwantoro:1997).

Beberapa konsep kepemimpinan yaitu 1) kepemimpinan merupakan suatu kemampuan untuk mempengaruhi suatu kelompok kearah pencapaian tujuan. Kemampuan yang berupa sifat-sifat yang dibawa sejak lahir yang ada pada diri seorang pemimpin, 2) kepemimpinan sebagai fungsi kelompok (function of the group) menurut konsep tersebut sukses tidaknya suatu kepemimpinan tidak hanya dipengaruhi oleh kemampuan sifatsifat yang ada pada seseorang tetapi justru yang lebih penting adalah dipengaruhi 
oleh sifat-sifat dan ciri-ciri kelompok yang dipimpinnya, dan 3) kepemimpinan dipandang sebagai suatu fungsi dari situasi (function of the situation), konseptersebut menunjukkan bahwa kepemimpinan seorang pemimpin telah memiliki sifat-sifat kepemimpinan yang baik dan dapat menjalankan fungsinya sebagai anggota kelompok, sukses tidaknya kepemimpinan masih ditentukan oleh situasi yang selalu berubah dan perubahannya selalu mempengaruhi perkembangan kehidupan kelompok yang dipimpinnya (Purwantoro:1997).

Berdasarkan konsep tersebut di atas maka pengertian kepemimpinan dapat ditelaah dari berbagai segi seperti dikemukakan oleh Sergeovani (1987), sebagai berikut : 1) kepemimpinan dapat dirumuskan sebagai suatu kepribadian (personality) seorang yang mendatangkan keinginan pada kelompok orang-orang untuk mencontohnya atau mengikutinya, atau yang memancarkan suatu pengaruh tertentu, suatu kekuatan atau wibawa yang sedemikian rupa sehingga membuat sekelompok orang mau melakukan apa yang dikehendakinya, 2) kepemimpinan dapat pula dipandang sebagai penyebab dari pada kegiatan-kegiatan, proses atau kesediaan untuk mengubah pandangan atau sikap (mental/fisik) dari pada kelompok orang-orang, baik dalam hubungan organisasi formal maupun non formal, 3) kepemimipinan adalah suatu seni (art), kesanggupan (ability) atau tehnik (tecnigue) untuk membuat sekelompok orang bawahan dalam organisasi formal atau para pengikut dalam organisasi informal mengikuti atau mentaati segala apa yang dikehendakinya, 4) kepemimpinan dipandang sebagai suatu bentuk persuasi suatu seni pembinaan kelompok orang-orang tertentu, biasanya melalui "human relations" dan motivasi yang tepat, sehingga mereka tanpa adanya rasa takut mau bekerja sama dan membanting tulang untuk memahami dan mencapai segala apa yang menjadi tujuan organisasi, 5) kepemimpinan dipandang sebagai suatu sarana, suatu instrumen atau alat, untuk membuat sekelompok orang-orang mau bekerja sama dan berupaya mentaati segala peraturan untuk mencapai tujuan yang telah ditentukan.

Berdasarkan pandangan tersebut di atas dapat disimpulkan bahwa kepemimpinan adalah sekumpulan dari serangkaian kemampuan dan sifat-sifat kepribadian termasuk didalamya kewibawaan, untuk dijadikan sebagai sarana (motor penggerak) dalam rangka menyakinkan yang dipimpinnya agar mereka mau dan dapat melaksanakan tugas-tugas yang dibebankan kepadanya dengan rela, penuh semangat, ada kegembiraan batin, serta tidak merasa terpaksa.

\section{Fungsi dan Tipe Kepemimpinan}

a. Fungsi Kepemimpinan

Kepemimpinan yang efektif hanya akan terwujud apabila dijalankan sesuai dengan fungsinya. Fungsi kepemimpinan itu berhubungan langsung dengan situasi sosial dalam kehidupan kelompok/organisasi masing-masing yang mengisyaratkan bahwa setiap pemimpin berada di dalam dan bukan di luar situasi itu. Fungsi kepemimpinan itu memiliki dua dimensi sebagai berikut: (1) Dimensi yang berkenaan dengan tingkatkemampuan mengarahkan (direction) dalam tindakan atau aktivitas pemimpin, yang terlibat pada tanggapan orang-orang yang dipimpin, (2) Dimensi yang berkenaan dengan tingkat dukungan (support) atau keterlibatan orang-orang yang dipimpin dalam melaksanakan tugastugas pokok kelompok/organisasi, yang dijabarkan dan dimanifestasikan melalui keputusan-keputusan dan kebijaksanaankebijaksanaan pemimpin.

Berdasarkan kedua dimensi tersebut, selanjutnya secara singkat dapat dibedakan lima fungsi pokok kepemimpinan antara lain : (1) Fungsi instruksi yaitu fungsi yang berlangsung dan bersifat komunikasi satu arah, (2) Fungsi konsuitatif yaitu yang berlangsung/bersifat komunikasi dua arah, (3) Fungsi partisipasi yaitu fungsi yang tidak sekedar berlangsung/bersifat 
dua arah tetapi berwujud pelaksanaan hubungan manusia yang efektif antara pemimpin dengan yang dipimpin, (4) Fungsi delegasi yaitu fungsi yang dilaksanakan dengan memberikan pelimpahan wewenang membuat/menetapkan keputusan, baik melalui persetujuan dari pimpinan, (5) Fungsi pengendalian yaitu fungsi yang dapat diwujudkan dengan melalui kegiatan bimbingan, pengarahan, koordinasi dan pengawasan (Nawawi, 1997).

b. Tipe Kepemimpinan

Max Weber melihat ada tiga tipe kepemimpinan yaitu : (1) Tradisional. ialah pemegangkekuasaan (otoriter) dalam kepemimpinan yang didasarkan atas keturunan atau warisan, (2) Karismatik, ialah pemegang kekuasaan dalam kepemimpinan karena memiliki sifat - sifar karismatik atau kewibawaan, (3) Rational ialah pemegang kekuasaan dalam struktur organisasi yang didasarkan atas peraturan atau undang undang (Fajar, 1993).

Sedangkan menurut Lewin, L. Dan Withe ada tiga tipe kepemimpinan yaitu: (1) Otoriter ialah model kepemimpinan yang menurut kemampuannya sendiri, mendominasi kelompok yang dipimpinnya, (2) Demokratis adalah model kepemimpinan yang terbuka segala sesuatu diambil atas dasar musyawarah, (3) Laissez Faire, berjalan sendiri-sendiri, terserah apa maunya anggotanya (Fajar, 1993).

Selain itu ada suatu bentuk kepemimpinan yang disebut Pscudo Demokrasi yaitu suatu bentuk kepemimpinan demokratis yang semu, artinya seorang pemimpin yang mempunyai sifat pescudo demokratis hanya menampakkan sikapnya saja yang demokratis, dibalik kata-katanya yang penuh tanggung jawab ada siasat yang sebenarnya merupakan tindakan absolut. Pemimpin yang pscudo demokratispenuh dengan manipulasi, sehingga pendapalnya sendiri yang harus disetujui.(Soetopo, 1998).

\section{Teori Kepemimpinan Situasional}

Semula teori ini dikembangkan oleh pusat studi Kepemimpinan di Ohio University dari konsep model keefektifan pemimpin ditinjau dari tiga dimensi (Three Dimensional Leader Effectiveness Model), yakni dimensi perilaku pemimpin dalam melaksanakan tugas, dimensi perilaku pemimpin dalam mengadakan hubungan interpersonal dengan bawahannya, dan dimensi tingkat kedewasaan bawahan dalam melaksanakan tugas pekerjaannya. Dua dimensi pertama (dimensi perilaku pemimpin dalam melaksanakan tugas dan dimensi perilaku pemimpin dalam mengadakan hubungan interpersonal) menentukan gaya kepemimpinan. Sedangkan kesesuaian tipe gaya kepemimpinan terhadap dimensi tingkat kedewasaan bawahan menentukan keefektifan gaya kepemimpinan.

Dimensi tingkat kedewasaan bawahan diasumsikan sebagai faktor yang paling dominan dalam menentukan pola atau gaya kepemimpinan yang efektif. Oleh karena itu tekanan utama teori ini terletak pada perilaku pemimpin dalam kaitannya dengan tingkat kedewasaan kemampuan bawahan, yakni kemampuan bawahan dalam melaksanakan tugas pekerjaannya. Ada dua faktor yang berkaitan dengan tingkat kedewasaan bawahan dalam melaksanakan pekerjaannya, yakni: pertama, kemampuan dalam pengetahuan teknis dalam melaksanakan pekerjaan,kedua, faktor kedewasaan psikologis yangberkaitan dengan emosi, motivasi, harga diri dan percaya diri terhadap tugas pekerjaannya.

Bawahan yang memiliki tingkat kedewasaan yang tinggi atas pekerjaannnya, dan memiliki kemampuan dan pengetahuan bagaimana melaksanakan pekerjaannya, memiliki emosi, motivasi, percaya diri, dan harga diri yang tinggi dalam melaksanakan pekerjaannya. Sebaliknya, bawahan yang rendah tingkat kedewasaannya, memiliki tingkat kemampuan dan pengetahuan yang rendah serta motivasi, emosi, percaya diri, dan harga diri yang rendah terhadap pekerjaannya, Makin tinggi 
tingkat kedewasaan bawahan, makin tinggi kemampuan, kreativitas, semangat kerja dan tanggung jawab bawahan terhadap pelaksanaan pekerjaannya, begitu juga sebaliknya. Berdasarkan kedua faktor tersebut tingkat kedewasaan bawahan, diklasifikasikan 4 tingkat kedewasaan yaitu :
a. Tingkat kedewasaan 1, berkemampuan rendah dan berkemauan rendah
b. Tingkat kedewasaan 2 berkemampuan tinggi dan berkemauan rendah
c. Tingkat kedewasaan 3, berkemampuan rendah dan berkemauan tinggi
d. Tingkat kedewasaan 4 berkemampuan tinggi dan berkemauan tinggi.

\section{Fungsi Kepala Sekolah}

Menurut Sergiovanni dan Eliot, (1987) secera esensial keberadaan seorang kepala sekolah memiliki dua fungsi utama bagi sekolah yang dikelolanya. Pertama, kepala sekolah sebagai administrator. Dalam fungsi ini, kepala sekolah bertugas melaksanakan fungsi-fungsi administrasi pendidikandi sekolah. Tugas-tugas tersebut meliputi pengelolaan yang bersifat administratif dan operatif. Kedua, kepala sekolah sebagai educator. Dalam fungsi ini, kepala sekolah bertugas menjalankan fungsifungsi edukatif dalam proses pendidikan di sekolah.

Pengelolaan yang bersifat adminstratif yang dilakukan kepala sekolah terdiri atas kegiatan-kegiatan yang bertujuan mengarahkan agar semua orang yang terlibat di sekolah mengerjakan hal-hal yang tepat, sesuai dengan tujuan sekolah yang hendak dicapai. Sedangkan pengelolaan yang bersifat edukatif merupakan kegiatan yang mengarahkan dan membina setiap guru agar mslaksanakan tugas pengajaran secara tepat dan benar.

Menurut Kyte (1972) seorang kepala sekolah memiliki lima fungsi utama. Pertama bertanggung jawab atas keselamatan, kesejahteraan, dan perkembangan murid-murid yang ada di lingkungan sekolah. Kedua, bertanggung jawab atas kesejahteraan dan keberhasilan profesi para guru. Ketiga, bertanggung jawab memberikan layanan sepenulmya yang berharga bagi muridmurid dan guru-guru yang mungkin dilakukan melalui pengawasan resmi yang lain. Keempat, bertanggung jawab mendapatkan bantuan maksimal dari semua institusi pembantu. Keiima, bertanggung jawab untuk mempromosikan murid-murid terbaik melalui berbagai cara.

Menurut Sergiovanni dan Eliot, (1987)bahwa peran kepala sekolah dalam administrasi meliputi pertanggung jawaban pada guru dan pekerja lainnya, masing-masing mempunyai tugas yang ditetapkan secara khusus. Sedangkantugas kepala sekolah mengkoordinasi, mengarahkan, dan mensupport kerja guru dan staf adalah mencapai tujuan yang ditetapkan, mengevaluasi untuk kerja, memberi sumberdaya yang dibutuhkan, membangun iklim psikologis yang mendukung, melibatkan diri terus menerus dengan orang tua, merencanakan dan menjadwal kegiatan, menertibkan tata buku, menyelesaikan konflik guru, menangani problem murid, berhubungan dengan kantor pusat sekolah, dan membantu yang lain menjaga perselisihan. Peran administrasi dan peran kepala sekolah ini sulit dipisahkan keduanya karena merupakan elemen yang saling menyeimbangkan. Keberhasilan kepala sekolah dalam kepemimpinan dan administrasi memiliki satu arah dan tujuan yaitu the improvement of teaching and learning for students.

\section{Keefektifan Kepala Sekolah}

Akhir-akhir ini banyak dilakukan tentang penelitian sekolah yarg efektif atau sering juga disebut sekolah yang sukses atau sekolah yang excellent (Sergiovanni, 1987). Untuk mengetahui faktor-faktor yang menentukan efektif tidaknya suatu sekolah, ada beberapa pendekatan. Salah satu pendekatan 
pencapaian tujuan. Model tersebut didasarkan pada pandangan tradisional yang mengatakan bahwa keefektifan suatu organisasi ditentukan oleh pencapaian tujuan ditandai dengan prestasi lulusan sekolah dalam bidang ketrampilan dasar yang diukur melalui tes prestasi standar.

Model yang lain adalah, model sistem, atau disebut juga dengan pendekatan proses atau pendekatan multidimensional. Dalam prespektif model sistem ini, baik tidaknya sekolah tidak hanya dilihat dari tingkat pencapaian tujuan, melainkan proses kondisinya, yang disebut dengan karakteristik sekolah. Sebagaimana yang dikatakan oleh Owens (1991) ada dua karakteristik sekolah. Pertama adalah karakteristik internal yang meliputi gaya kepemimpinan, proses komunikasi, sistem supervisi, evaluasi pengajaran, kedisiplinan dan proses pembuatan keputusan. Kedua, karakterisrik eksternal sekolah yang meliputi keadaan lingkungan sekitar organisasi, seperti karakteristik masyarakat, tradisi sosio kultural, struktur kekuatan politik, dan demografinya.

Kedua teori tersebut memang tampak berbeda. Namun keduanya saling melengkapi satu sama lain, sehingga mungkin perlu dikombinasikan agar dapat menghasilkan suatu pernyataan sekolah yang efektif sebagaimana pendapat dari Hoy \& Miskel (1987).

Selanjutnya menurut Weingartoer (1989) tentang sekolah yang efektif atau excellent adalah sekolah yang mengkombinasikan indikator model tujuan dan model sistem sekolah yang efektif, dikatakan efektif apabila sekolah memiliki seperangkat fungsi esensial. Fungsi-fungsi esensial itu meliputi : (1) Perstrukturan waktu, (2) Perstrukturan aktifitas, (3) Pendefinisian kecerdasan, (4) Penilaian, (5) Pemisahan peran dan antara guru dan murid (6) Supervisi dan pengawasan terhadap murid (7) Pertanggungjawaban sekolah terhadap Masyarakat. pengawasan terhadap murid
(7) Pertanggungjawaban sekolah terhadap masyarakat.

\section{Gaya Kepemimpinan}

Gaya kepimpinan menurut Hersey \& Blanchard (1982) adalah perilaku pemimpin yang ditujukkan pada saat ia mempengaruhi bawahannya. Pada dasarnya kecenderungan perilaku pemimpin diklasifikasikan menjadi dua kecenderungan. Pertama, perilaku bersifat direktif atau otokratis dinamakan initiating stucture, dan kedua, perilaku bersifat supportif atau demokratis dinamakan consideration.

Perilaku Initiating Stuctureadalah perilaku pemimpin yang cenderung mengacu pada tuntutan organisasi dalam mencapai tujuannya, berdasarkan otoritas pemimpin dalam struktur organisasi yang bersifat memberikan pengarahan. Perilaku ini tampak pada tuntutan yang relatif tinggi terhadapa bawahan dalam mematuhi tata tertib yang berlaku (disiplin), pengawasan bersifat ketat, komunikasi satu arah, menetapkan peranan bawahan, memberitahu bawahan tentang apa yang harus dikerjakan, bagaimana mengerjakannya, dimana dan bila pekerjaan tersebut dikerjakan.

Perilaku considerationadalah perilaku pemimpin yang cenderung memenuhi kebutuhan individu atau manusia yang ada dalam organisasi. Perilaku ini tampak pada perhatian pemimpin yang lebih besar terhadap pemenuhan kebutuhan anggota organisasi, mengikutsertakan bawahan dalam proses pengambilan keputusan dan pemecahan masalah, komunikasi bersifat duaarah, suka mendengarkan dan memperhatikan pendapat bawahannya, dana pengawasannya tidak terlalu ketat.

Dengan mengkombinasikan kedua perilaku pemimpin (initiating stucture dan consideration) diperoleh empat gaya kepemimpinan, yakni gaya kepemimpinan instruksi, konsultasi, partisipasi dan delegasi seperti terlihat dalam gambar pada gambar berikut: 


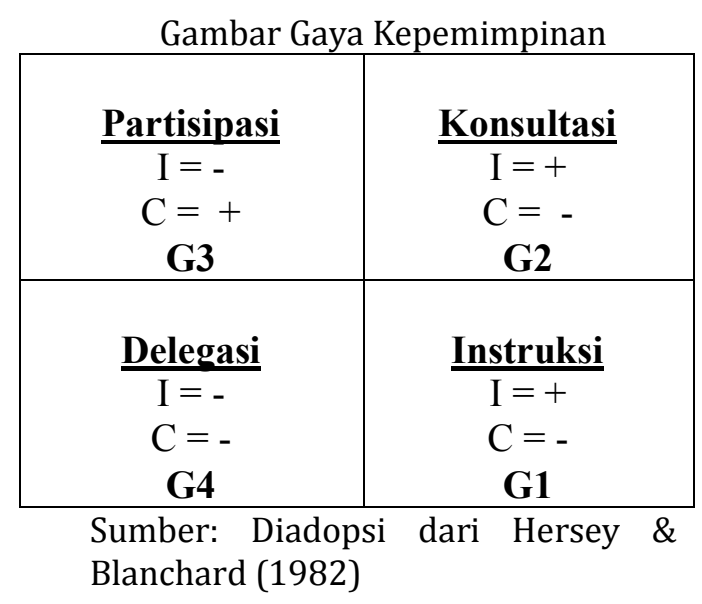

Keterangan:
a. I = Inisiasi,
C - Konsiderasi
b. Garis Horisontal : menggambarkan pemimpinmakin kekanan makin tinggi, begitu pula sebaliknya.
c. Garis Vertikal : menggambarkan perilaku konsiderasi pemimpin (c) makin keatas makin tinggi, begitu pula sebaliknya.
d. $\mathrm{Gl}=$ Gaya Instruksi $(\mathrm{I}=+; \mathrm{C}=-)$
G2 = Gaya Konsultasi $(\mathrm{I}=+; \mathrm{C}=+)$
G3 - Gaya Partisipasi $(\mathrm{I}=-; \mathrm{C}=+$ )
G4 = Gaya Delegasi $(\mathrm{I}=-; \mathrm{C}=-$ )

1. Gaya Instruksi (Gl)

$\mathrm{Gl}$ adalah gaya kepemimpinan dimana perilaku struktur inisiasinya relatif tinggi dan perilaku considerationnya relatif rendah indikatorya antara lain: (a) banyak memberi pengarahan dan sedikit memberi kesempatan berpartisipasl kepada bawahan, (b) instruksi yang diberikan kepada bawahan terinci secara spesifik, (c) pengawasan dilakukan secara ketat, (d) proses komunikasi bersifat searahdari atas ke bawah, (e) peranan bawahan dibatasi, (f) inisiatif pengambilan keputusan dan pemecahan masalah datang dari pemimpin, dan (g) pemimpin menentukan apa, bagaimana, dan bilamana bawahan melaksanakan tugasnya.

2. Gaya Konsultasi (G2)

Gaya kepemimpinan ini ditandai prilaku struktur inisiasinya relatif banyak mendengarkan pendapat dan saran bawahannya. Pemimpin memberi kesempatan kepada bawahan dalam proses pengambilan keputusan, akan tetapi ia masih memberikan pengarahan dan pengawasan terhadap pelaksanakan tugas yang dilakukan bawahannya. Pemimpin banyak mendengarkan pendapat bawahan dan mendorong untuk melaksanakan tugas sesuai dengan tata aturan yang berlaku. Pemimpin dan bawahan bertukar pendapat dalam proses pemecahan masalah dan pengambilan keputusan. Dengan demikian proses komunikasinya bersifat dua arah.

3. Gaya Partisispasi (G3)

Gaya kepemimpinan ini ditandai dengan prilaku struktur inisiasinya relatif rendah dan prilaku konsiderasinya relatif tinggi, indikator prilakunya antara lain, pengarahan dan pengawasan pemimpin berkurang, sebaliknya ia lebih banyak mendengarkan dan memperhatikan pendapat dan saran bawahan dalam proses pengambilan keputusan dan pemecahan masalah pemimpin memberi dorongan kepada bawahan dan memberi bimbingan kepada bawahan dalam pemecahan permasalahan yang tidak dapat dipecahkan sendiri oleh bawahan.Pemimpin menganggap bawahan sebagai mitra kerjanya, sehingga hubungan kerjanya bersifat kolegial. 
4. Gaya Delegasi (G4)

Gaya kepemimpinan ini ditandai dengan prilaku struktur inisiasinya relatif rendah dan prilaku konsiderasinya juga relatif rendah, indikator prilakunya antara lain: (a) Pemimpin relatif sering mendelegasikan wewenang dan tanggung jawabnya kepada bawahan dalam pelaksanaan program kerjanya, (b) bawahan mendapatkan kesempatan yang luas dalam proses pengambilan keputusan dan pemecahan masalah, (c) Pemimpin menaruh kepercayaan pada kemampuan bawahan dalam melaksanakan tugas yang diberikan, dan (d) meyadari bahwa bawahan dapat memikul tanggung jawab atas pelaksanaan tugasnya dan dapat menyelesaikan tugas tepat pada waktunya.

Fiedler

mengungkapkan bahwa tidak ada gaya kepemimpinan yang efektif dapat diterapkan dalam segala situasi dan kondisi, selanjutnya ia juga mengatakan bahwa keefektifan suatu gaya kepemimpinan diterapkan oleh ketetapan atau relevansi penerapannya pada tingkat kedewasaan kemampuan bawahan dalam melaksanakan fungsi dan tugasnya (situasi dan kondisinya). Jadi variabel tingkat kedewasaan bawahan menentukan keefektifan suatu gaya kepemimpinan.

Tingkat $\begin{array}{r}\text { kedewasaan } \\ \text { bawahan }\end{array}$
kemampuan kemampuan
merupakan tingkat keman
dan tingkat kemauan bawahan
dalam melaksanakan fungsi dan
tugas yang dibebankan
kepadanya. Kemampuan
bawahan berkaitan denagn
pengetahuan dan ketrampilan
bawahan yang diperoleh dan
pendidikan, pelatihan dan

pengalaman, sedangkan kemauan bawahan berkaitan dengan motivasi dan semangat kerja bawahan serta kepuasan akan hasil kerjanya. Perlu diketahui bahwa konsep tingkat kedewasaan kemampuan bawahan berkaitan dengan suatu tugas yang spesifik. Oleh karena itu setiap bawahan cenderung berada tingkat kedewasaan yang berbeda-beda tergantung pada tugas spesifik yang yang sedang ia hadapi. Konsekwensinya suatu gaya kepemimpinan tidak selamanya efektif diterapkan pada seorang atau sekelompok bawahan yang berada pada situasi yang berbeda-beda.

Muclas Samani menyusun suatu model keefektifan gaya kepemimpinan berdasarkan teori kepemimpinan. Model tersebut dapat menggambarkan keefektifan setiap gaya kepemimpinan bila diterapkan pada situasi (tingkatkedewasaan dan kemampuan bawahan) yang tepat. Model kepemimpinan tersebut dapat dilihat pada gambar sebagai berikut:

Gambar Gaya Kepemimpinan

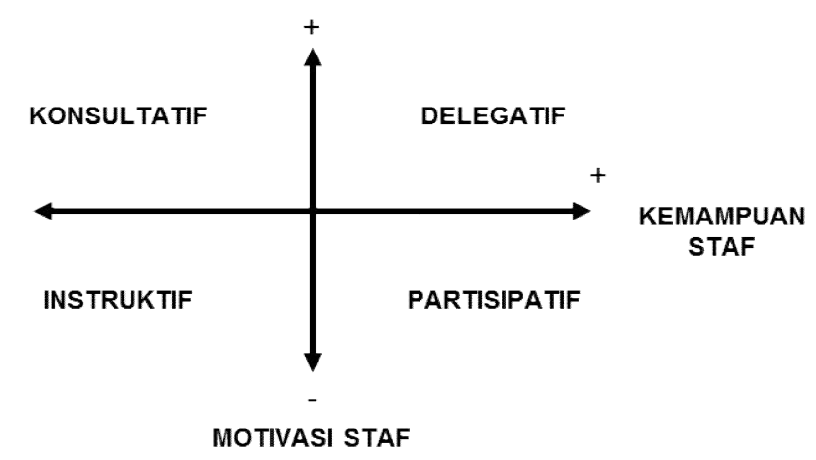

Sumber: Diadopsi dari Muchlas Samani (2000)

Keterangan:

a. Jika menghadapi staf yang 
memiliki kemampuan baik dan motivasi kerja juga baik, maka gaya kepemimpinan delegatif paling baik. Artinya kepala sekolah lebih banyak memberikan dukungan dan mendelegasikan tugas dan wewenang kepada staf.

b. Jika menghadapi staf yang memiliki kemampuan yang baik, tetapi motivasi kerjanya kurang, maka gaya kepemimpinan partisipatif paling efektif. Artinyakepala sekolah berpartisipasi aktif dalam mendorong staf untuk menggunakan kemampuaanya secara optimal.

c. Jika menghadapi staf yang memiliki kemampuan yang kurang baik, tetapi memiliki motivasi kerja baik, maka gaya kepemimpinan konsultatif penting.

\section{Peningkatan Mutu Proses Dan Hasil Pendidikan}

1.Kemampuan Personal dan Tugas Guru

Proses belajar mengajar merupakan inti dari kegiatan pendidikan di sekolah. Agar tujuan pendidikan dan pengajaran tercapai secara efektif kegiatan belajar mengajar perlu dikelola seoptimal mungkin, pengelolaan kegiatan belajar mengajar merupakan bagian administrasi kurikulum. Menurut Moch. Rifai, tugas dan peran guru sebagai pendidik profesional sesungguhnya sangat kompleks, tidak terbatas pada saat berlangsungnya interaksi edukatif di dalam kelas yang lazim disebut proses belajar (Subroto, 1997).

Dalam buku Petunjuk Pelaksanaan Proses Belajar Mengajar, Kurikulum 1984Pendidikan Kejuruan disebutkan bahwa tugas guru dalam pengelolaan pengajaran sebagai berikut: 1) membuat program pengajaran, 2) mengorganisasi kelas dan siswa yang meliputi : (a)mengatur ruangan dan perabot pelajaran di kelas, (b) mengatur siswa dalam belajar dan (c) memilih metode belajar mengajar, dan 3) menggunakan sarana dan lingkungan sebagai sumber belajar (Depdikbud, 1985).

Sedangkan Suharsimi Arikunto mengemukakan bahwa tugas guru adalah (1) mempelajari materi pelajaran (dalam GBPP) yang akan dijadikaii tuntunan dalam penyusunan rencana pelajaran, (2) memilih pendekatan atau strategi untuk menyampaikan pelajaran, (3) memilih alat-alat pelajaran dan sarana lain, (4) memilih strategi evaluasi yang akan diambil (Subroto, 1997).

\section{Peningkatan Mutu Proses Pendidikan}

Berbagai unsur penyelenggaraan pendidikan dapat kita ketahuibetapa sulitnya peningkatan mutu pendidikan, sehingga peningkatan mutu pendidikanmerupakan suatu syarat mutlak untuk mempercepat terwujudnya suatu masyarakatyang cerdas. Untuk meningkatkan mutu itu perlunya perencanaan yang melibatkan komponen personalia sekolah sebagimana pendapat Pidarta (1990) bahwa perencanaan yang baik adalah perencanaan dari kalangan pendidikan maupun dari kalangan masyarakat.

Dalam konteks pendidikan, pengertian mutu mencakup input, proses dan output pendidikan. Input pendidikan adalah segala sesuatu yang harus tersediakarena dibutuhkan untuk berlangsungnya pendidikan. Proses pendidikan merupakan berubahnya sesuatu menjadi sesuatu yang lain. Output pendidikan merupakan prestasi sekolah yang dihasilkan dari proses pembiasaan perilaku sekolah. Outputpendidikan dikatakan bermutu tinggi jika prestasi sekolah khususnya prestasi siswa, menunjukkan pencapian yang tinggi dalam : (1) prestasi akademik, berupa nilai ulangan umum, unas, UN, karya ilmiah, lomba-lomba akademik, dan (2) prestasi non-akademik seperti misalnya IMTAQ, kejujuran, kesopanan, olah raga, kesenian, keterampilan kejujuran, dan kegiatankegjatan ektrakurikuler lainnya.

Kunci utama didalam meningkatkan kualitas pendidikan adalah mutu para gurunya. Dalam proses belajar mengajar guru memegang peran yang sangat 
penting. Guru adalah kreator proses belajar mengajar, mengembangkan potensi, melalui tiga ranah pembelajaran, yaitu (1) Kognisi, (2) Afeksi dan (3) Psikomotor. (Tilaar, 1992).

Untuk dapat mampu melaksanakan tugas mengajar dengan baik, guru harus memiliki kemampuan profesional, yaitu menguasai 10 kompetensi guru yang meliputi: 1) menguasai bahan, 2) Mengelola program belajar mengajar, 3) mengelola kelas, 4) Penggunaan media atau sumber yang meliputi : (a) mengenal, memilih dan mcnggunakan media, (b) membuat alat bantu pelajaranyang sederhana, (c) menggunakan perpustakaan dalam proses belajar mengajar dan (d) menggunakan Micro teaching untuk unit program pengenalan lapangan, 5) menguasai landasanlandasan pendidikan, 6) mengelola interaksi-interaksi belajar mengajar, 7) menilai prestasi siswa untuk kepentingan pelajaran, 8) mengenal fungsi layanan bimbingan dan penyuluhan, 9) mengenal dan menyelenggarakan administrasi sekolah dan 10) memahami prinsipprinsip dan menafsirkan hasil penelitian pendidikan guna keperluan pengajaran (Depdikbud, 1995).

Selain itu untuk mencapai keberhasilan proses pendidikan, Hudamengemukakan bahwa proses untuk meningkatkan efisiensi dalam pendidikan adalah dengan mengakomodasi aspirasi masyarakat sekitar karena dipandang bahwa sekolah sebagai suatu sistem sosial. Komponen sistem sosial tersebut digambarkan sebagai berikut (Huda, 1998 : 3-12).
Tampak bahwa kualitas lulusan sangat dipengaruhi oleh proses belajar mengajar (PBM). Sedangkan PBM itu sendiri dipengaruhi oleh komponen instrumental input terutama guru dan pengelola/kepala sekolah. Olehkarenanya upaya peningkatan mutu pendidikan dapat diasumsikan identik dengan peningkatan kualitas gurunya. Tiap komponen beserta faktor-faktor pada meningkatkan kualitas gurunya. Tiap komponen beserta faktor-faktor pada gambar 2.3 tersebut saling terkait sehingga membentuk suatu sistem (Dekdikbud, 1995).

Dengan demikian paparan gambar tersebut di atas dapat disimpulkan bahwa PBM dipengaruhi oleh sekitarnya dianaranya adalah kepemimpinan kepala sekolah yang memiliki implikasi terhadap peningkatan kualitas guru yang berdampak terhadap proses belajar mengajar. Dengan adanya peningkatan mutu guru maka akan berdampak terhadap mutu lulusan atau output dan outcome.

\section{Hubungan Antara Kepemimpinan Dengan Peningkatan Mutu Pendidikan}

Mutu pendidikan dapat terwujud dipengaruhi oleh beberapa faktor. Faktor yang mempengaruhi antara lain berasal dari kepemimpinan kepala sekolah dalam memimpin dan menstimulasi guru dan karyawan, penyediaan sarana dan prasarana pembelajaran, kemampuan guru dalam proses pembelajaran, kondisi peserta didik dalam menyerap bahan ajar, pemberian evaluasi dan dukungan dari berbagai pihak. Terwujudnya hal tersebut

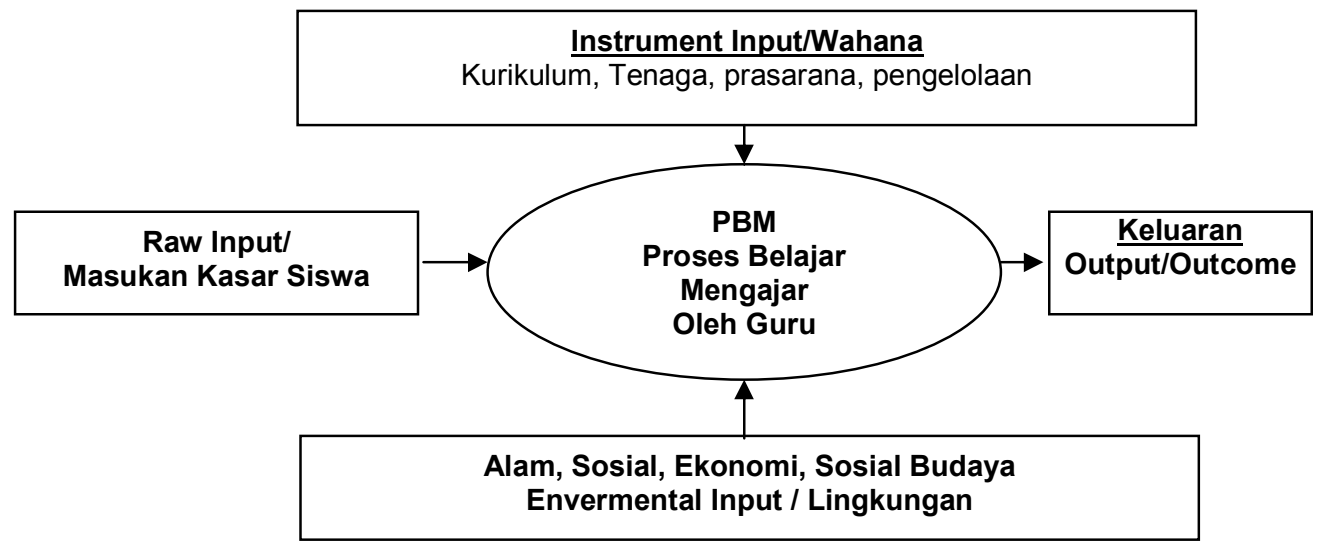


sebagian besar ditentukan oleh peran dan fungsi kepemimpinan kepala sekolah.

\section{Kesimpulan}

Berdasarkan uraian diatas maka dalam hal ini dapat disimpulkan sebagai berikut:

1. Kepemimpinan kepala sekolah harus memperhatikan mutu pendidikan, dimana kepala sekolah harus mampu mengoptimalkan peran strategisnya dalam pengelolaan organisasi sekolah.

2. Kepemimpinan kepala sekolah merupakan sekumpulan dari serangkaian kemampuan dan sifatsifat kepribadian termasuk didalamya kewibawaan, untuk dijadikan sebagai sarana (motor penggerak) dalam rangka menyakinkan yang dipimpinnya agar mereka mau dan dapat melaksanakan tugas-tugas yang dibebankan kepadanya dengan rela, penuh semangat, ada kegembiraan batin, serta tidak merasa terpaksa.

3. Peran dan fungsi kepemimpinan kepala sekolah dalam menggerakan warga sekolah dilakukan dengan optimal untuk peningkatan mutu pendidikan.

\section{Daftar Pustaka}

Arikunto, Suharsimi 1985. Pengelolaan Kelas dan Siswa. Jakarta : CV. Rajawali.

Davis, G,A and Thomas, M,A. 1994, Efective Schools and Effective Teachers Boston: Allyr and Bacon, Inc. De Roche, Edward, F 1996. How School Administration Solve Problems. New Jensey : prentice hall.

Effendi, A.R. 1997. Dasar-dasar Manajemen Pendidikan untuk meningkatkan kualitas Sekolah Dasar. Malang: IKIP.
Fajar, A.M.1993. Administrasi dan Supervisi dan Pendidikan. Yogyakarta: Aditya Media.

Hersey, P dan Blanchard, K,H. 1982. Management of Organizational Behavior : Utilizing Human Resource. 4 th. Ed. New Jersey : Prentice Hall, Inc.

Hoy, W.K. dan Miskel, L.G. 1987. Educational Administration : Theory, Research and Practice. Secind ed New York: Random House, Inc.

Huda, Nuril 1998. Decentralisation of Education in Indonesia^ ${ }^{\wedge}$ Jurnal Ilmu Pendidikan 5 (01)

Kurniawan. 1996. Menyikapi maraknya Sekolah Unggulan, Suara pembaharuan.

Kyte, G.C. 1972. The Principle at Work Revised Edition, Boston: Ginn ang Company.

Me R.B. Crowson, Pherson R.L. 1986. Managing Uncertainty: Administrative Theory and Practice in Education. Colombus: Charles E. Marriel Publishing Company.

Nawawi, H. 1997. Administrasi Pendidikan. Jakarta: Gunung Agung.

Owens, R.G. 1991. Organisasi behavior in Education. 4 th Ed. Boston: ellyn and bacon, Inc.

Peraturan Pemerintah R.I. No. 28/1990 tentang Pendidikan Dasar. Pidarta, Made. 1997. Landasan Kependidikan. Jakarta: Rineka Cipta.

Pidarta, Made. 1990. Perencanaan Pendidikan Partisipatori dengan Pendekatan Sistem. Jakarta: Rineka Cipta.

Pidarta, Made. 2001. Desentralisasi Pendidikandi Tingkat Kabupaten, Jurnal Pendidikan. 8 (01)

Purwanto, N. 1997. Ilmu Pendidikan Teoritis dan Praktis. Bandung : remaja Rosdakarya.

Samani ,Muchlas. 2000. Manajemen Sekolah. Jakarta : Depdiknas 
Sergiovanni dan Eliot. 1987. The Principalship : A Reflective Practive Perspective Boston: Allyn and Bacon Inc.

Slamet, PH. 2000. Managemen Berbasis Sekolah, Jurnal Pendidikan dan Kebudayaan, 6 (07)

Soetopo, H. 1998. Kepemimpinan dan Supervise Pendidikan. Jakarta : Bina Aksara IKAPI

Suryosubroto, B. 1997. Proses Belajar Mengajar di Sekolah, Jakarta : PT. Rineka Cipta.

Tilaar, H.A.R. 1992. Manajemen Pendidikan Nasional, Kajian Pendidikan Masa Depan. Bandung: Remaja Rosdakarya.
Tilaar, H.A.R. 2000 Manajemen Pendidikan Nasional, Kajian Pendidikan Masa Depan. Bandung : Remaja Rosdajarya.

Undang Undang Republik Indonesia. 2003. Tentang Sistem Pendidikan Nasional Jakarta: Depdiknas.

Weingartner C. 1989. The School Book New York:Delacorte Press. 